\title{
The BCL2L11 deletion polymorphism is not associated with imatinib resistance in chronic myeloid leukemia patients: meta- analysis
}

\author{
Jinyun $\mathrm{Xu}^{1,2}$, Jiaowei $\mathrm{Gu}^{2}$, Yan Zhao ${ }^{2}$, Huihua Meng ${ }^{1}$, Li'an $\mathrm{Du}^{1}$, Ruibo Zhang ${ }^{2}$, Hao \\ Jiang ${ }^{2}$ and Jianming Luo ${ }^{1}$ \\ ${ }^{1}$ Department of Pediatrics, The First Affiliated Hospital of Guangxi Medical University, Nanning, Guangxi, China \\ ${ }^{2}$ Department of Pediatrics, Taihe Hospital, Hubei University of Medicine, Shiyan, Hubei, China
}

Correspondence to: Jianming Luo, email: ljm_erke@126.com

Keywords: BIM, chronic myeloid leukemia, tyrosine kinase inhibitor, genetic polymorphism, drug resistance

Received: August 01, 2017 Accepted: September 04, $2017 \quad$ Published: September 22, 2017

Copyright: Xu et al. This is an open-access article distributed under the terms of the Creative Commons Attribution License 3.0 (CC BY 3.0), which permits unrestricted use, distribution, and reproduction in any medium, provided the original author and source are credited.

\section{ABSTRACT}

A common deletion polymorphism of the gene Bcl-2 like protein 11 (BCL2L11, BIM) has been reported to cause tyrosine kinase inhibitors (TKIs) resistance in several malignant tumors. However, the conclusions were not consistent in chronic myeloid leukemia (CML) individuals. In order to obtain a reliable conclusion, we systematically searched PubMed, Embase, Web of Science, Chinese Biomedical Database, and China National Knowledge Infrastructure and performed the meta-analysis. Six published articles contain 760 East Asian patients were identified from these electronic databases. The methodological quality of one included trial was high, and the others were moderate. Meta-analysis showed that the rate of TKI resistance between the BIM deletion and wild-type group were no statistical significance (OR $=1.24,95 \%$ CI 0.79-1.95). In conclusion, BIM deletion may not a predictor of TKI resistance in CML individuals in East Asia.

\section{INTRODUCTION}

Chronic myeloid leukemia (CML) is a malignancy of hematology caused by the reciprocal chromosomal translocation $\mathrm{t}(9 ; 22)$ and constitutively active BCR-ABL $[1$, $2]$, which affects about one individual per 100,000 population per year [3-6]. Usually, the clinical course of CML is characteristically triphasic: Chronic phase, acceleration and blast crisis, and symptoms are controlled more easily in chronic phase [4]. Fortunately, most patients tend to be diagnosed in the chronic phase [7,8], and the treatment to this phase has improved over the past decades [1,9-14].

Since 1996, Druker et al. [2] reported a novel compound (imatinib) for the effect of the tyrosine kinase inhibitor (TKI) on CML cell lines. In 2001, imatinib was approved for the treatment of CML in phase 2 studies [15]. In recent years, imatinib was used as the front-line treatment of chronic phase CML patients all over the world [1, 6, 14, 16-24]. However, the rate of imatinib resistance have been reported about $20 \%$, and even more if added imatinib intolerance [22-24]. Thus, further in-depth analysis of the mechanisms of imatinib resistance in CML patients are necessary.
$\mathrm{Ng}$ et al. [25] recently identified a common intron 2 deletion polymorphism in the gene encoding Bcl-2 like 11 (BCL2L11, BIM). The BIM deletion polymorphism appeared to occur at a frequency of $12.3 \%$ individuals only in East Asia, and showed an inferior response to tyrosine kinas inhibitors (TKIs) when compared to those without the deletion in CML patients [25]. In addition, this common BIM deletion may predict relapse after TKI discontinuation [26]. However, other studies suggested that BIM deletion was not significantly associated with the TKI efficacy for CML patients [27, 28]. Accordingly, we decided to conduct the meta-analysis of currently available studies to assess the relationship between BIM deletion and imatinib resistance in CML patients.

\section{RESULTS}

Literature search and study selection

We identified 28 records from PubMed, 71 records from Embase, 66 records from Web of Science and none from CBD and CNKI. After reviewing the titles and 
abstracts, we obtained 23 possible involvement articles and get these full-text articles for further evaluation. In these 23 possible articles from three different data-bases, there were 13 duplicates. Two articles contain duplicate data, one study without enough data and one reply were excluded from the last 10 articles. Ultimately, 6 articles $[25,27-31]$ including 8 studies were enrolled in the study. No additional trials were identified by checking the reference lists. The study selected process was depicted in Figure 1.

\section{Characteristics and quality of the studies}

There were 6 articles [25, 27-31] involving 760 patients included in this meta-analysis. All of the patients were treated with imatinib as the front-line treatment except that one study switching to nilotinib after more than 18 months' treatment of imatinib [30]. All of the included patients were reported in chronic phase with positive BCR-ABL fusion gene and the primary outcome was on the basis of the European LeukemiaNet (ELN) criteria.

Only 1 study-data was obtained prospectively from multi-center [27], and others were retrospective analysis. One trial received the quality score of 4 [30] and two received $5[29,31]$, illustrated that the methodological quality was low. The characteristics and quality score of each study were presented in Table 1 .

There was no significant asymmetry in funnel plots for the outcomes between the BIM deletion and wild genotype by TKI treatment (Figure 2).

\section{Data synthesis}

According to the ELN criteria [24], we preformed meta-analysis to synthesize these results through TKIresistant rate (Table 2 and Figure 3). The rate of TKIresistance in CML patients who harbored BIM deletion or not were no statistical significance $(\mathrm{OR}=1.24,95 \% \mathrm{CI}$ $0.79-1.95)$. There was no statistical significance between included studies in heterogeneity $\left(\mathrm{I}^{2}=34 \%, P=0.15\right)$. There were similar results whether we calculate OR or RR, and no matter we used the fixed or random model (Table 2).

There were two articles contain 3 studies which defined the results in the same manner on the basis of the ELN $[25,28]$. Then, we performed subgroup analysis using these data (Figure 4). There was significant heterogeneity in this subgroup, we performed meta-analysis using random-effects model. There was no statistical significance between the two groups at the rate of TKI-resistance.

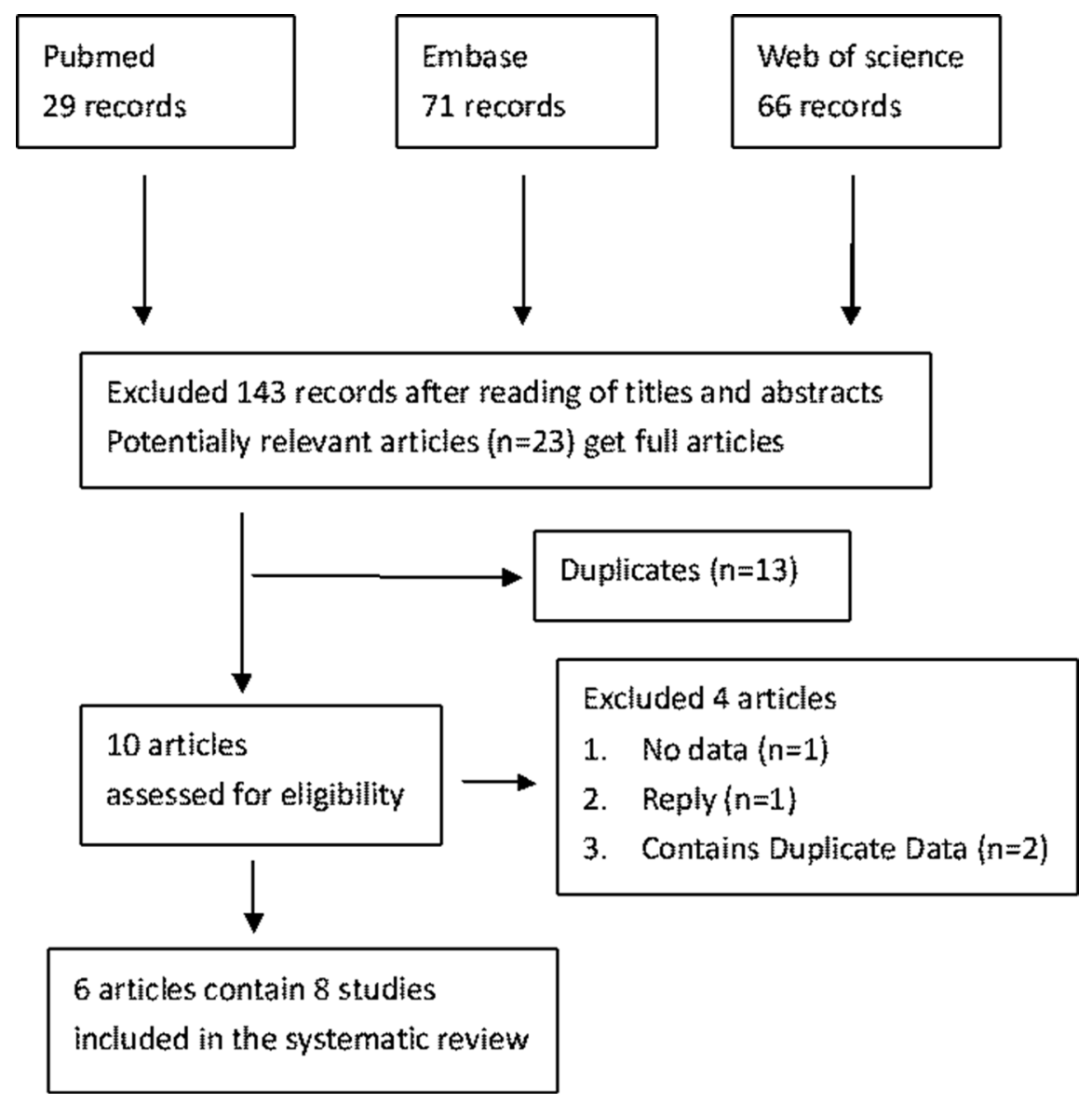

Figure 1: Flowchart of the study identification. 
Table 1: Characteristics of the included researches

\begin{tabular}{|c|c|c|c|c|c|c|c|c|c|c|c|}
\hline Study ID & Country & $\begin{array}{c}\text { Sample } \\
\text { size }\end{array}$ & $\begin{array}{c}\text { BIM } \\
\text { deletion }\end{array}$ & Bcr-abl & Drugs dose & $\begin{array}{l}\text { Sensitive/ } \\
\text { Resistant }\end{array}$ & Study design & $\begin{array}{c}\text { Data } \\
\text { sources }\end{array}$ & standard & outcome & NOS score \\
\hline $\mathrm{Ng} 2012 \mathrm{~A}$ & $\begin{array}{l}\text { Singapore } \\
\text { Malaysia }\end{array}$ & 138 & 15 & + & $\begin{array}{c}\text { Imatinib } \\
0.4 \mathrm{~g} / \mathrm{d}\end{array}$ & $\begin{array}{c}69 / \\
69\end{array}$ & retrospective & Multi-center & ELN & $\begin{array}{l}\text { Sensitive } \\
\text { Resistant }\end{array}$ & 9 \\
\hline $\mathrm{Ng} 2012$ B & Japan & 65 & 12 & + & $\begin{array}{c}\text { Imatinib } \\
0.4 \mathrm{~g} / \mathrm{d}\end{array}$ & $\begin{array}{c}25 / \\
40\end{array}$ & retrospective & Multi-center & ELN & $\begin{array}{l}\text { Sensitive } \\
\text { Resistant }\end{array}$ & 9 \\
\hline $\begin{array}{c}\text { Katagiri } \\
2013 \text { A }\end{array}$ & Japan & 37 & 2 & + & $\begin{array}{c}\text { Imatinib } \\
\text { NA }\end{array}$ & $\begin{array}{c}20 / \\
17\end{array}$ & retrospective & Single center & ELN & $\begin{array}{c}\text { Sustained or } \\
\text { fluctuating CMR } \\
>24 \text { month }\end{array}$ & 5 \\
\hline $\begin{array}{c}\text { Katagiri } \\
2013 \text { B }\end{array}$ & Japan & 13 & 3 & + & $\begin{array}{c}\text { Imatinib } \\
\text { NA }\end{array}$ & $\begin{array}{l}5 / \\
8\end{array}$ & retrospective & Single center & ELN & $\begin{array}{c}\text { Maintained CMR } \\
>12 \text { OR }<12 \\
\text { month after stop } \\
\text { imatinib }\end{array}$ & 5 \\
\hline $\begin{array}{c}\text { Shinohara } \\
2013\end{array}$ & Japan & 144 & 15 & + & $\begin{array}{c}\text { Imatinib } \\
0.4 \mathrm{~g} / \mathrm{d}\end{array}$ & $\begin{array}{l}72 / \\
72\end{array}$ & prospective & Multi-center & ELN & CMR & 6 \\
\hline Chen 2014 & China & 220 & 30 & + & Imatinib & $\begin{array}{c}140 / \\
80\end{array}$ & retrospective & Multi-center & ELN & $\begin{array}{l}\text { Sensitive } \\
\text { Resistant }\end{array}$ & 7 \\
\hline $\begin{array}{c}\text { Miyamura } \\
2016\end{array}$ & Japan & 40 & 3 & + & $\begin{array}{l}\text { Nilotinib } \\
\text { after Imatinib } \\
0.4 \mathrm{~g} / \mathrm{d} 18 \\
\text { month }\end{array}$ & $\begin{array}{c}27 / \\
13\end{array}$ & retrospective & Multi-center & ELN & $\begin{array}{c}\text { MMR at } 24 \\
\text { months }\end{array}$ & 4 \\
\hline Than 2016 & Japan & 103 & 15 & + & Imatinib & $\begin{array}{c}89 / \\
14\end{array}$ & retrospective & Single center & ELN & 10 -year OS & 5 \\
\hline
\end{tabular}

CMR, complete molecular response; +, positive; d, day; NA, not available; ELN, European LeukemiaNet; MMR, major molecular response; OS, overall survival.

\section{DISCUSSION}

It is well known that the gene BIM encodes a Bcl-2 homology domain 3 (BH3) only protein, which is a proapoptotic member of B-cell lymphoma 2 (Bcl-2) family $[32,33]$. BIM could induce hematologic cancer cell death through apoptotic pathway [32]. Previous studies have shown that imatinib activated pro-apoptotic $\mathrm{BH} 3$-only protein BIM, which is regarded as a major role in imatinib induced apoptosis of the BCR-ABL1 positive CML cells [34, 35]. However, a common 2903 bp intron deletion polymorphism of BIM leads to the preferential generation lack the $\mathrm{BH} 3$ domain and it may correlated with inferior response to TKI in CML patients [25]. Notably, there were three studies reported the contradictory results $[27$, $28,30]$. Hence, we used data from published studies and performed this meta analysis.

In this study, we found that BIM intron 2 deletion polymorphism was not associated with TKI resistance in CML patients $(\mathrm{OR}=1.24,95 \%$ CI $0.79-1.95)$. In subgroup analysis, we combined data from two studies $[25,28]$ and also found similar result $(\mathrm{OR}=1.42,95 \%$

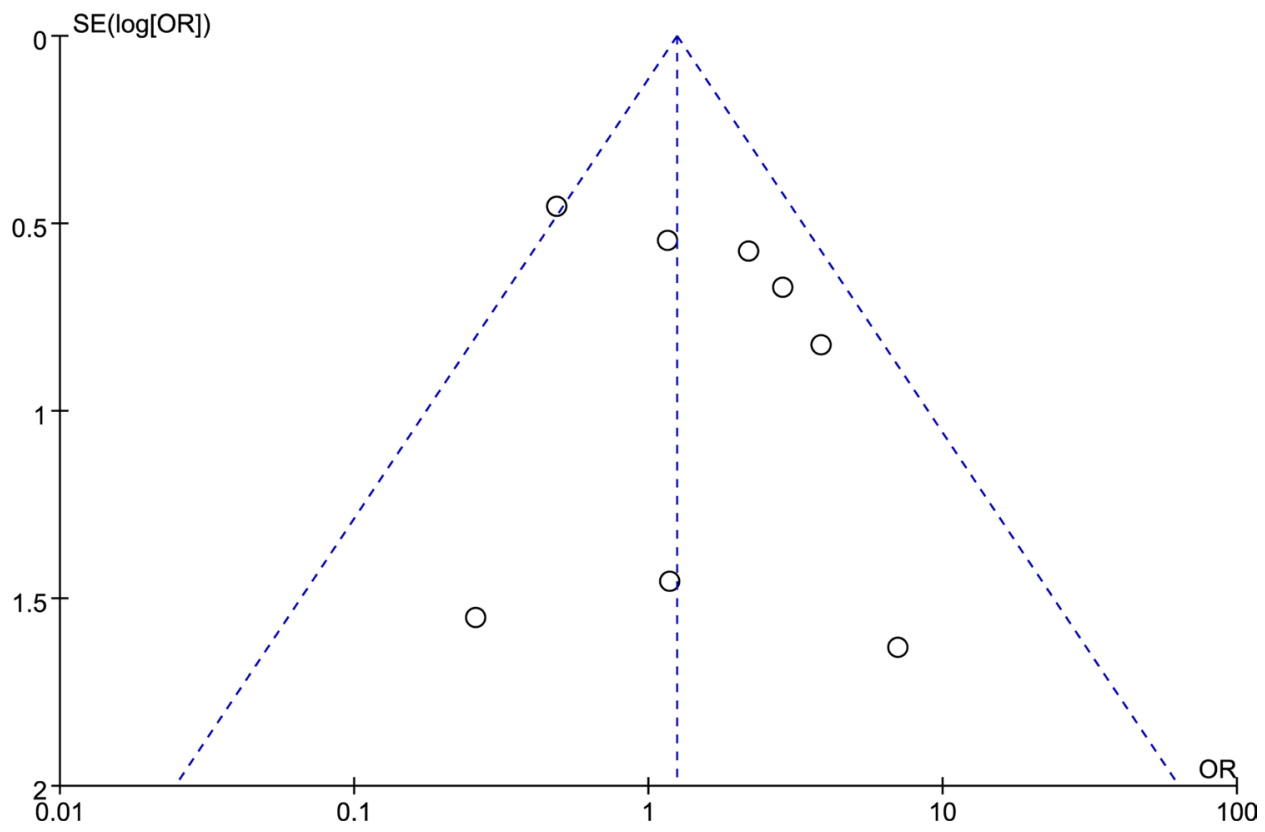

Figure 2: Funnel plot of TKI-resistance between the BIM deletion and wild-type. 
Table 2: The results of Meta-analysis between BIM deletion type and wild type in resistance to TKI

\begin{tabular}{ccccc}
\hline Effect measures & Effect model & $\mathbf{I}^{2}(\boldsymbol{P})$ & $\mathbf{9 5 \%} \mathbf{C I}$ & $\boldsymbol{P}$ \\
\hline OR & fixed & $34 \%(P=0.15)$ & $1.24(0.79-1.95)$ & 0.35 \\
OR & random & & $1.42(0.73-2.73)$ & 0.30 \\
RR & fixed & $37 \%(P=0.14)$ & $1.12(0.89-1.41)$ & 0.34 \\
RR & random & & $1.26(0.95-1.68)$ & 0.11 \\
\hline
\end{tabular}

OR: odds ratio, RR: risk ratio, CI: confidence intervals

CI 0.40-5.03). These results suggesting that BIM deletion polymorphism may be not associated with clinical efficacy of TKI therapy in CML individuals in East-Asian.

Recent studies showed that dasatinib [11] and nilotinib $[12,13]$ was superior to imatinib in both major molecular response and complete cytogenetic response. Even in patients with CML who are resistant to imatinib therapy, dasatinib may induces notable response $[1,10]$. When patients with BIM polymorphisms experience a suboptimal response to imatinib, switching to nilotinib would benefit them [30]. In summary, if BIM deletion was associated with imatinibresistance, the common BIM deletion would become a symbol of excluded imatinib for treating CML in East-Asian. However, the results of the systematic review proved that this common BIM deletion were not related to clinical relevance of imatinib-resistance. We suggested that this common BIM deletion should not used as a symbol of discontinuation of imatinib or switching imatinib to other TKIs.
Nowadays, TKI targeting BCR-ABL1 is the standard of care for patients with CML in chronic phase $[9,17,18,30,36,37]$. Response during TKI therapy is the most important prognostic factor for long-term outcome in CML. Since there are not enough evidences suggesting that BIM deletion polymorphism is related to TKIresistance in CML patients, we propose the common BIM deletion should not serve as a biomarker for determining the prognosis in CML patients with the treatment of TKIs.

There is only one study reported a subset of non high-risk CML patiets and found that BIM deletion was associated with inferior 10 years over survivors [31]. Nevertheless, the result is from a retrospective study and the included number of individuals are small so that further investigation is warranted.

There are several reasons affecting the quality of evidence. Firstly, this systematic review included only published trails. Secondly, the quality score of each trials

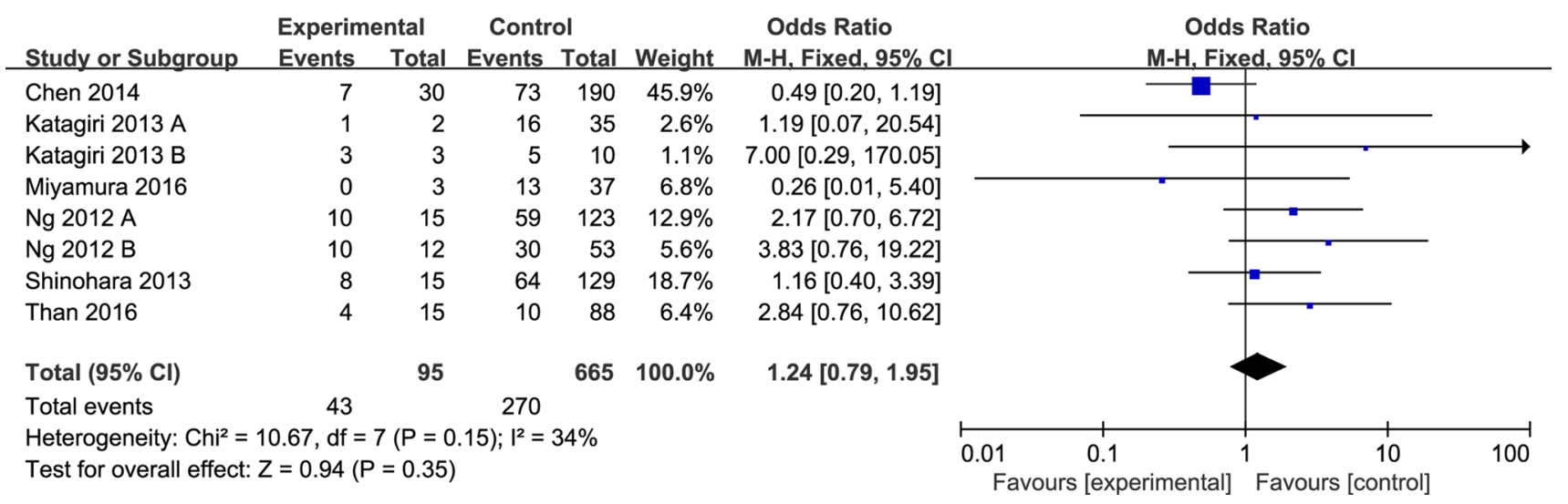

Figure 3: Meta-analysis of the association between the BIM deletion polymorphism and imatinib-resistance in CML patients.

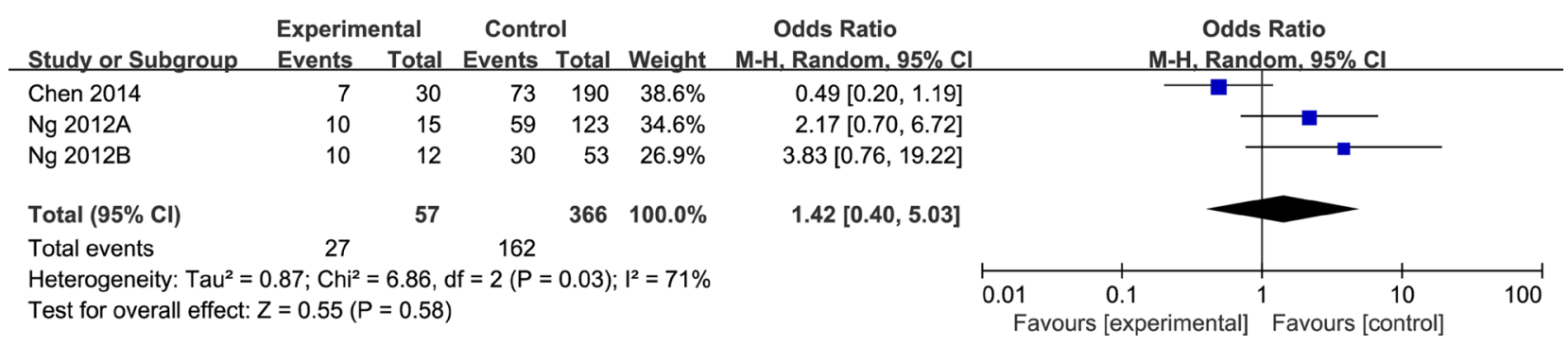

Figure 4: Subgroup analysis of two articles which defined the results in a same manner. 
could be graded as moderate except one [25]. Thirdly, the results between studies were defined inconsistently. Fourthly, there were no randomized controlled trails.

In conclusion, this systematic review and meta analysis shows that the common BIM deletion is not associated with TKI-resistance in CML patients in East Asian. Through this systematic review, we also suggest that the common BIM deletion should not be served as an indicator to discontinue imatinib or switching imatinib to other TKIs. However, further prospective studies included large trails which defined the results with widely accepted criteria are essential.

\section{MATERIALS AND METHODS}

We used different search strategies and searched more electronic databases than those by Ying et al. [38]. The recommendations of the preferred reporting items for systematic review and meta-analysis were the main methods used for this study [39].

\section{Literature search}

We comprehensively searched PubMed, Embase, Web of Science, Chinese Biomedical Database (CBD), and China National Knowledge Infrastructure (CNKI) from inception until May 2017. Keywords and search terms were as following, "BIM OR BCL2L11 OR Bcl-2 like 11" AND "deletion OR polymorphism" AND "CML OR chronic myeloid leukemia OR chronic leukemia". Next, we searched reference lists of all included articles for additional relevant trial. There was no language restrictions.

\section{Inclusion and exclusion criteria}

We included relevant articles if they fulfilled the following eligibility criteria. (1) Retrospective or prospective studies which investigated the association between BIM deletion polymorphism and TKI efficacy of CML patient. (2) There were sufficient data concerning outcomes. (3) patients were receiving TKIs therapy. (4) response assessments were according to the international guidelines. Conversely, review, meta-analysis and case report were excluded. If there were any studies with duplicated data, we included only one which with larger sample size and more information.

\section{Literature screening and data extraction}

Two review authors (Jinyun and Jiaowei) assessed all of the studies searched from the databases through titles and abstracts. We obtained the full articles if some papers may satisfied our criteria and then reviewed the literatures carefully to decided whether included or not. At last, reference list of eligible studies were identified. If there were any disagreements between the two reviewers about study inclusion, we resolved them by discussion in our study group.

The author Jinyun extracted study details from the included trials. These data were verified by another two authors ( Yan Zhao and Jiaowei ).

\section{Assessment of risk of bias}

Two reviewers (Jinyun and Jiaowei) independently assessed the risk of bias in all included studies according to an assessment tool of the Newcastle-Ottawa Scale (NOS) that is recommended by the Cochrane Collaboration $[40,41]$. The score of the methodological quality of all included studies were range from 0 to 9 , which the higher score represented the higher quality. Disagreements were resolved by discussion in our group.

\section{Statistical meta analysis}

RevMan 5.3 was used for this meta-analysis. For Dichotomous data, we calculated odds ratios (OR) or risk ratios (RR) corresponding $95 \%$ confidence intervals (CI). The heterogeneity was evaluated by the $\mathrm{Q}$ test and $\mathrm{I}^{2}$ statistic. The $\mathrm{I}^{2}$ statistic ranges from $0 \%$ to $100 \%$, a value of $0 \%$ indicated no observed heterogeneity and larger values show increasing heterogeneity [42]. If the $\mathrm{I}^{2}<50 \%$ and $P$ value $\geq 0.1$, we considered heterogeneity was no significance and used the fixed effects model for analysis. Otherwise, the potentially inconsistency among all included trails were analyzed carefully, if the heterogeneity was not excluded we used the random-effects model.

\section{Author contributions}

Jianming Luo, Jinyun Xu and Yan Zhao designed the study. Jinyun Xu and Jiaowei Gu assessed all articles. All authors contributed the primary study data, performed the statistically analysis. Jinyun $\mathrm{Xu}$ wrote the first manuscript. All collaborators revised and final approval this manuscript.

\section{CONFLICTS OF INTEREST}

We state no conflicts of interest.

\section{REFERENCES}

1. Talpaz M, Shah NP, Kantarjian H, Donato N, Nicoll J, Paquette R, Cortes J, O'Brien S, Nicaise C, Bleickardt E, Blackwood-Chirchir MA, Iyer V, Chen TT, et al. Dasatinib in imatinib-resistant Philadelphia chromosome-positive leukemias. N Engl J Med. 2006; 354:2531-41. https://doi. org/10.1056/NEJMoa055229.

2. Druker BJ, Tamura S, Buchdunger E, Ohno S, Segal GM, Fanning S, Zimmermann J, Lydon NB. Effects of a selective 
inhibitor of the Abl tyrosine kinase on the growth of BcrAbl positive cells. Nat Med. 1996; 2:561-6.

3. Kim DW, Banavali SD, Bunworasate U, Goh YT, Ganly P, Huang H, Irving I, Jootar S, Goh HG, Koh LP, Li W, Naoe T, Ng SC, et al. Chronic myeloid leukemia in the Asia-Pacific region: current practice, challenges and opportunities in the targeted therapy era. Leuk Res. 2010; 34:1459-71. https://doi.org/10.1016/j.leukres.2010.03.033.

4. Apperley JF. Chronic myeloid leukaemia. Lancet. 2015; 385:1447-59. https://doi.org/10.1016/S01406736(13)62120-0.

5. Hoglund M, Sandin F, Simonsson B. Epidemiology of chronic myeloid leukaemia: an update. Ann Hematol. 2015; 94:S241-7. https://doi.org/10.1007/s00277-015-2314-2.

6. Baccarani M, Pileri S, Steegmann JL, Muller M, Soverini $\mathrm{S}$, Dreyling M; and ESMO Guidelines Working Group. Chronic myeloid leukemia: ESMO Clinical Practice Guidelines for diagnosis, treatment and follow-up. Ann Oncol. 2012 (Suppl 7); 23:vii72-77. https://doi. org/10.1093/annonc/mds228.

7. Valent P, Herndlhofer S, Schneeweiss M, Boidol B, Ringler A, Kubicek S, Gleixner KV, Hoermann G, Hadzijusufovic E, Mullauer L, Sperr WR, Superti-Furga G, Mannhalter C. TKI rotation-induced persistent deep molecular response in multi-resistant blast crisis of $\mathrm{Ph}+\mathrm{CML}$. Oncotarget. 2017; 8:23061-72. https://doi.org/10.18632/oncotarget.15481.

8. Au WY, Caguioa PB, Chuah C, Hsu SC, Jootar S, Kim DW, Kweon IY, O’Neil WM, Saikia TK, Wang J. Chronic myeloid leukemia in Asia. Int J Hematol. 2009; 89:14-23. https://doi.org/10.1007/s12185-008-0230-0.

9. Kantarjian H, Sawyers C, Hochhaus A, Guilhot F, Schiffer C, Gambacorti-Passerini C, Niederwieser D, Resta D, Capdeville R, Zoellner U, Talpaz M, Druker B, Goldman $\mathrm{J}$, et al, and International STI571 CML Study Group. Hematologic and cytogenetic responses to imatinib mesylate in chronic myelogenous leukemia. N Engl J Med. 2002; 346:645-52. https://doi.org/10.1056/NEJMoa011573.

10. Hochhaus A, Kantarjian HM, Baccarani M, Lipton JH, Apperley JF, Druker BJ, Facon T, Goldberg SL, Cervantes F, Niederwieser D, Silver RT, Stone RM, Hughes TP, et al. Dasatinib induces notable hematologic and cytogenetic responses in chronic-phase chronic myeloid leukemia after failure of imatinib therapy. Blood. 2007; 109:2303-9. https://doi.org/10.1182/blood-2006-09-047266.

11. Kantarjian H, Shah NP, Hochhaus A, Cortes J, Shah S, Ayala M, Moiraghi B, Shen Z, Mayer J, Pasquini R, Nakamae $\mathrm{H}$, Huguet F, Boque C, et al. Dasatinib versus imatinib in newly diagnosed chronic-phase chronic myeloid leukemia. N Engl J Med. 2010; 362:2260-70. https://doi.org/10.1056/ NEJMoa1002315.

12. Saglio G, Kim DW, Issaragrisil S, le Coutre P, Etienne G, Lobo C, Pasquini R, Clark RE, Hochhaus A, Hughes TP, Gallagher N, Hoenekopp A, Dong M, et al, and ENESTnd Investigators. Nilotinib versus imatinib for newly diagnosed chronic myeloid leukemia. N Engl J Med. 2010; 362:22519. https://doi.org/10.1056/NEJMoa0912614.

13. Kantarjian HM, Hochhaus A, Saglio G, De Souza C, Flinn IW, Stenke L, Goh YT, Rosti G, Nakamae H, Gallagher NJ, Hoenekopp A, Blakesley RE, Larson RA, et al. Nilotinib versus imatinib for the treatment of patients with newly diagnosed chronic phase, Philadelphia chromosomepositive, chronic myeloid leukaemia: 24-month minimum follow-up of the phase 3 randomised ENESTnd trial. Lancet Oncol. 2011; 12:841-51. https://doi.org/10.1016/S14702045(11)70201-7.

14. Hoffmann VS, Baccarani M, Hasford J, Castagnetti F, Di Raimondo F, Casado LF, Turkina A, Zackova D, Ossenkoppele G, Zaritskey A, Hoglund M, Simonsson B, Indrak K, et al. Treatment and outcome of 2904 CML patients from the EUTOS population-based registry. Leukemia. 2017; 31:593-601. https://doi.org/10.1038/leu.2016.246.

15. Cohen MH, Williams G, Johnson JR, Duan J, Gobburu J, Rahman A, Benson K, Leighton J, Kim SK, Wood R, Rothmann M, Chen G, U KM, et al. Approval summary for imatinib mesylate capsules in the treatment of chronic myelogenous leukemia. Clin Cancer Res. 2002; 8:935-42.

16. Wang J, Shen ZX, Saglio G, Jin J, Huang H, Hu Y, Du X, Li J, Meng F, Zhu H, Hu J, Wang J, Hou M, et al. Phase 3 study of nilotinib vs imatinib in Chinese patients with newly diagnosed chronic myeloid leukemia in chronic phase: ENESTchina. Blood. 2015; 125:2771-8. https://doi. org/10.1182/blood-2014-09-601674.

17. Pallera A, Altman JK, Berman E, Abboud CN, Bhatnagar B, Curtin P, DeAngelo DJ, Gotlib J, Hagelstrom RT, Hobbs G, Jagasia M, Kantarjian HM, Kropf P, et al. NCCN Guidelines Insights: Chronic Myeloid Leukemia, Version 1.2017. J Natl Compr Canc Netw. 2016; 14:1505-12.

18. Hochhaus A, Larson RA, Guilhot F, Radich JP, Branford $\mathrm{S}$, Hughes TP, Baccarani M, Deininger MW, Cervantes F, Fujihara S, Ortmann CE, Menssen HD, Kantarjian H, et al, and IRIS Investigators. Long-Term Outcomes of Imatinib Treatment for Chronic Myeloid Leukemia. N Engl J Med. 2017; 376:917-27. https://doi.org/10.1056/ NEJMoa1609324.

19. Takahashi N, Tauchi T, Kitamura K, Miyamura K, Saburi Y, Miyata Y, Hatta Y, Kimura F, Takada S, Fukuda T, Fujimaki K, Ishikawa M, Matsumura I, et al. Around 70\% of Japanese CML Patients Could Stop Imatinib According to a-STIM Criteria: The JALSG-STIM213 Study. Blood. 2015; $126: 4035$

20. Hughes TP, Saglio G, Quintas-Cardama A, Mauro MJ, Kim DW, Lipton JH, Bradley-Garelik MB, Ukropec J, Hochhaus A. BCR-ABL1 mutation development during first-line treatment with dasatinib or imatinib for chronic myeloid leukemia in chronic phase. Leukemia. 2015; 29:1832-8. https://doi.org/10.1038/leu.2015.168.

21. Hehlmann R, Lauseker M, Jung-Munkwitz S, Leitner A, Muller MC, Pletsch N, Proetel U, Haferlach C, 
Schlegelberger B, Balleisen L, Hanel M, Pfirrmann M, Krause SW, et al. Tolerability-adapted imatinib 800 $\mathrm{mg} / \mathrm{d}$ versus $400 \mathrm{mg} / \mathrm{d}$ versus $400 \mathrm{mg} / \mathrm{d}$ plus interferonalpha in newly diagnosed chronic myeloid leukemia. J Clin Oncol. 2011; 29:1634-42. https://doi.org/10.1200/ JCO.2010.32.0598.

22. Druker BJ, Guilhot F, O’Brien SG, Gathmann I, Kantarjian H, Gattermann N, Deininger MW, Silver RT, Goldman JM, Stone RM, Cervantes F, Hochhaus A, Powell BL, et al, and IRIS Investigators. Five-year follow-up of patients receiving imatinib for chronic myeloid leukemia. N Engl J Med. 2006; 355:2408-17. https://doi.org/10.1056/NEJMoa062867.

23. Hochhaus A, O'Brien SG, Guilhot F, Druker BJ, Branford S, Foroni L, Goldman JM, Müller MC, Radich JP, Rudoltz M, Mone M, Gathmann I, Hughes TP, Larson RA, and IRIS Investigators. Six-year follow-up of patients receiving imatinib for the first-line treatment of chronic myeloid leukemia. Leukemia. 2009; 23:1054-61. https://doi. org/10.1038/leu.2009.38.

24. Baccarani M, Deininger MW, Rosti G, Hochhaus A, Soverini S, Apperley JF, Cervantes F, Clark RE, Cortes JE, Guilhot F, Hjorth-Hansen H, Hughes TP, Kantarjian $\mathrm{HM}$, et al. European LeukemiaNet recommendations for the management of chronic myeloid leukemia: 2013. Blood. 2013; 122:872-84. https://doi.org/10.1182/ blood-2013-05-501569.

25. Ng KP, Hillmer AM, Chuah CT, Juan WC, Ko TK, Teo AS, Ariyaratne PN, Takahashi N, Sawada K, Fei Y, Soh $\mathrm{S}$, Lee WH, Huang JW, et al. A common BIM deletion polymorphism mediates intrinsic resistance and inferior responses to tyrosine kinase inhibitors in cancer. Nat Med. 2012; 18:521-8. https://doi.org/10.1038/nm.2713.

26. Katagiri S, Tauchi T, Saito Y, Sugro T, Asano M, Yoshizawa S, Sakuta J, Akahane D, Tanaka Y, Furuya N, Ando K, Fujimoto H, Okabe S, et al. BCL2L11 (BIM) Deletion Polymorphism Is Associated with Molecular Relapse after ABL Tyrosine Kinase Inhibitor Discontinuation in Patients with Chronic Myeloid Leukemia with Complete Molecular Response. Blood. 2014; 124: 1797.

27. Shinohara Y, Takahashi N, Nishiwaki K, Hino M, Kashimura M, Wakita H, Hatano Y, Hirasawa A, Nakagawa Y, Itoh K, Masuoka H, Aotsuka N, Matsuura Y, et al. A multicenter clinical study evaluating the confirmed complete molecular response rate in imatinib-treated patients with chronic phase chronic myeloid leukemia by using the international scale of real-time quantitative polymerase chain reaction. Haematologica. 2013; 98:140713. https://doi.org/10.3324/haematol.2013.085167.

28. Chen X, Liu H, Xing H, Sun H, Zhu P. The BIM deletion polymorphism cannot account for intrinsic TKI resistance of Chinese individuals with chronic myeloid leukemia. Nat Med. 2014; 20:1090. https://doi.org/10.1038/nm.3638.

29. Katagiri S, Umezu T, Ohyashiki JH, Ohyashiki K. The BCL2L11 (BIM) deletion polymorphism is a possible criterion for discontinuation of imatinib in chronic myeloid leukaemia patients. Br J Haematol. 2013; 160:269-72. https://doi.org/10.1111/bjh.12111.

30. Miyamura K, Miyamoto T, Tanimoto M, Yamamoto K, Kimura S, Kawaguchi T, Matsumura I, Hata T, Tsurumi H, Saito S, Hino M, Tadokoro S, Meguro K, et al. Switching to nilotinib in patients with chronic myeloid leukemia in chronic phase with molecular suboptimal response to frontline imatinib: SENSOR final results and BIM polymorphism substudy. Leuk Res. 2016; 51:11-8. https:// doi.org/10.1016/j.leukres.2016.09.009.

31. Than H, Lye WK, Seow CH, Sng CN, Allen JC, Chuah C. Genetic profiling augments prognostic value of the EUTOS long-term survival score for disease-specific mortality in imatinib-treated asian chronic myeloid leukaemia patients. Blood. 2016; 128: 3077.

32. LaBelle JL, Katz SG, Bird GH, Gavathiotis E, Stewart ML, Lawrence C, Fisher JK, Godes M, Pitter K, Kung AL, Walensky LD. A stapled BIM peptide overcomes apoptotic resistance in hematologic cancers. J Clin Invest. 2012; 122:2018-31. https://doi.org/10.1172/JCI46231.

33. Czabotar PE, Lessene G, Strasser A, Adams JM. Control of apoptosis by the BCL-2 protein family: implications for physiology and therapy. Nat Rev Mol Cell Biol. 2014; 15:49-63. https://doi.org/10.1038/nrm3722.

34. Kuroda J, Puthalakath H, Cragg MS, Kelly PN, Bouillet P, Huang DC, Kimura S, Ottmann OG, Druker BJ, Villunger A, Roberts AW, Strasser A. Bim and Bad mediate imatinibinduced killing of $\mathrm{Bcr} / \mathrm{Abl}+$ leukemic cells, and resistance due to their loss is overcome by a $\mathrm{BH} 3$ mimetic. Proc Natl Acad Sci U S A. 2006; 103:14907-12. https://doi. org/10.1073/pnas.0606176103.

35. Gordon PM, Fisher DE. Role for the proapoptotic factor BIM in mediating imatinib-induced apoptosis in a c-KIT-dependent gastrointestinal stromal tumor cell line. J Biol Chem. 2010; 285:14109-14. https://doi.org/10.1074/jbc.M109.078592.

36. Radich JP, Kopecky KJ, Appelbaum FR, Kamel-Reid S, Stock W, Malnassy G, Paietta E, Wadleigh M, Larson RA, Emanuel P, Tallman M, Lipton J, Turner AR, et al. A randomized trial of dasatinib $100 \mathrm{mg}$ versus imatinib 400 $\mathrm{mg}$ in newly diagnosed chronic-phase chronic myeloid leukemia. Blood. 2012; 120:3898-905. https://doi. org/10.1182/blood-2012-02-410688.

37. Pfirrmann M, Baccarani M, Saussele S, Guilhot J, Cervantes F, Ossenkoppele G, Hoffmann VS, Castagnetti F, Hasford J, Hehlmann R, Simonsson B. Prognosis of long-term survival considering disease-specific death in patients with chronic myeloid leukemia. Leukemia. 2016; 30:48-56. https://doi. org/10.1038/leu.2015.261.

38. Ying HQ, Chen J, He BS, Pan YQ, Wang F, Deng QW, Sun HL, Liu X, Wang SK. The effect of BIM deletion polymorphism on intrinsic resistance and clinical outcome of cancer patient with kinase inhibitor therapy. Sci Rep. 2015; 5:11348. https://doi.org/10.1038/srep11348.

39. Hutton B, Salanti G, Caldwell DM, Chaimani A, Schmid $\mathrm{CH}$, Cameron C, Ioannidis JP, Straus S, Thorlund K, Jansen 
JP, Mulrow C, Catala-Lopez F, Gotzsche PC, et al. The PRISMA extension statement for reporting of systematic reviews incorporating network meta-analyses of health care interventions: checklist and explanations. Ann Intern Med. 2015; 162:777-84. https://doi.org/10.7326/M14-2385.

40. Wells GA, Shea BJ, O'Connell D, Peterson J, Welch V, Losos M, Tugwell P. The Newcastle-Ottawa Scale (NOS) for Assessing the Quality of Non-Randomized Studies in Meta-Analysis. http://www.ohri.ca/programs/clinical_ epidemiology/oxford.asp. Accessed August 31, 2016.
41. Higgins JP, Green S. Cochrane Handbook for Systematic Reviews of Interventions Version 5.1.0 [updated March 2011]. The Cochrane Collaboration, (2011). Available from http://handbook.cochrane.org.

42. Higgins JP, Thompson SG, Deeks JJ, Altman DG. Measuring inconsistency in meta-analyses. BMJ. 2003; 327:557-60. https://doi.org/10.1136/bmj.327.7414.557. 